\section{Marshall Institute cuts} no ice in Britain

\section{London}

Members of the George C. Marshall Institute, a privately funded US body which argues that the threat from global warming is overestimated, received a hostile reception from the British press and the Department of the Environment last week when they criticized predictions made by the scientific panel of the Intergovernmental Panel on Climate Change (IPCC). Professor William Nierenberg and Jim Frelk, directors of the institute, argue that current models do not predict climate change accurately enough to be used to set government policy.

The institute rose from obscurity last year with the publication of a report which suggested that global warming correlates more closely with solar activity than with the increasing concentration of greenhouse gases, and that moderate global warming over the next century could prove beneficial by countering the effects of an expected 'little ice age'. The Marshall report was well received in the White House, but the UK Department of the Environment regretted that the Institute of Energy, which invited Frelk and Nierenberg to London, chose to present their views at a press conference, rather than at a debate with the institute's many scientific critics.

Both Frelk and Nierenberg said that cuts in greenhouse gas emissions should be delayed until further research produces models that can make accurate prediction on the regional effects of climate change. Frelk, a political scientist by training, expects these models to be available in three to five years. But Nierenberg, director emeritus of the Scripps Institution of Oceanography, said after the conference that this was "too optimistic" and that ten years would be a more realistic figure.

Nierenberg said that estimates of future greenhouse gas emissions used by the scientific panel of IPCC (group I) in its deliberations are too large. IPCC's group I predicted that if no action is taken to curb greenhouse gas emissions, global mean temperatures will rise by $3{ }^{\circ} \mathrm{C}$ before the end of the next century. Nierenberg said that if the estimates are made by projecting recent trends in greenhouse emissions, rather than by making assumptions about energy use in developing countries, the predicted rise is only $1^{\circ} \mathrm{C}$. But Professor Tom Wigley, from the University of East Anglia, says that he has calculated future emissions based on trends over the past ten years which are "very similar" to figures used by IPCC. Wigley is an author of IPCC group I's report, and also briefed the Marshall Institute on its report. He says that the institute was very selective in its use of his data.

Peter Aldhous

\title{
Regulations breached
}

\section{London}

Medical researchers at St Bartholomew's Hospital, London, transferring genes from the human gut parasite Giardia lamblia to Escherichia coli, broke UK regulations on the contained use of genetically manipulated organisms, according to Health and Safety Executive (HSE) inspectors who visited the hospital last month. It is the first recorded breach of the regulations.

Professor John Beringer, from the University of Bristol, who will chair a new committee to advise ministers on the release of genetically manipulated organisms into the environment, hopes the incident will draw attention to recent tightening of UK legislation. Genetic manipulation has become such a "simple" procedure, Beringer says, that some scientists are not aware of the regulatory framework that now exists.

Tony Taylor, secretary to the HSE's

\section{M. Klotz and J. J. Katz}

\section{An apology}

Nature wishes to put on record the following circumstances concerning the refusal of an article by Professor I. M. Klotz of Northwestern University and Dr J. J. Katz of the Argonne National Laboratory, both in Illinois.

Early in May, Klotz and Katz submitted for publication an article drawing attention to the close parallel between reports of the supposed discovery of Acarus crossii in the nineteenth century and those of 'cold fusion' that have more recently appeared. It was decided that the article should not be published in its original form, chiefly because of the required unhandy format (parallel columns detailing corresponding items of information). Two alternative courses of action were identified - either Klotz and Katz could be invited to recast their article or the author of the research that has uncovered the details of the Acarus crossii discovery, Dr James Secord, might be invited to write a separate article dealing with Acarus crossii alone. At no stage was it intended that the second course should be followed without consultation with Klotz and Katz.

In the event, through a series of errors in the Nature office, an article by Secord was commissioned, set in type and published without Klotz and Katz being consulted. Nature offers this apology to both authors for the distress and fury they have been occasioned as well as to Dr James Secord (who, needless to say, was throughout ignorant of the circumstances) for whatever embarrassment this regrettable affair may cause him. John Maddox Editor, Nature
Advisory Committee on Genetic Manipulation says that the researchers failed to notify HSE inspectors of their work, a legal requirement since 1978. St Bartholomew's lacked a Biological Safety Committee to oversee the work, and there had been no assessment of the health risk posed by the experiments. These two requirements were introduced last year.

Taylor believes breaches are "not a common occurrence" but, as with all statute law, "compliance is never 100 per cent". Julian Kinderlerer, from the University of Sheffield, a member of Beringer's new committee, is worried that some academic scientists regard the risks posed by their work as trivial, and are not complying with the law, but agrees with Beringer that ignorance of legislation may be a bigger problem. Until last year, the HSE had only to be informed about the initial manufacture of genetically manipulated organisms, but now their use must also be notified. "We have to make scientists aware" of their legal responsibilities, Kinderlerer says. Compliance in large industrial laboratories is thought to be better than in academic institutions but smaller companies may be more lax.

HSE has issued 'improvement notices', to Michael Farthing, of the gastroenterology laboratory at $\mathrm{St}$ Bartholomews, and the City and Hackney Health Authority, which runs the hospital.

Experiments can continue, provided legal requirements are met in future. Taylor says that the HSE decided against harsher action - serving "prohibition notices' immediately curtailing research, or prosecution - because the health risks posed were slight.

The breach at St Bartholomew's comes at a sensitive time as $U K$ regulations governing environmental releases of genetically manipulated organisms are to be drawn up within the next 12 months, to comply with a recent European Communities directive (see Nature 344, 371; 29 March 1990). Beringer says that an important task for the new advisory committee on environmental releases, which meets for the first time in July, will be to help draw up these regulations. He acknowledges that public access to information on applications for consents to release remains a "contentious" issue.

The Environmental Protection Bill (see Nature 343, 4; 1990), currently passing through parliament, notes that some information about proposed releases may be withheld on the grounds of "commercial confidentiality". Beringer says that some researchers are also worried that publication of full details of proposed releases may lead to experiments being sabotaged by environmentalist activists.

Peter Aldhous 